\title{
Concomitant Medication Group Identifier
}

National Cancer Institute

\section{Source}

National Cancer Institute. Concomitant Medication Group Identifier. NCI Thesaurus.

Code C83228.

A character or string that represents a concomitant medication group. 